\title{
High Temperature Corrosion and Protection of Ceramics, Composites and Silicides
}

\author{
Sébastien Chevalier • Bruce Pint • Daniel Monceau
}

Published online: 12 September 2013

(C) Springer Science+Business Media New York 2013

Presented in this focus issue of Oxidation of Metals is a series of informative papers that deal the high-temperature corrosion behavior of ceramics and silicides. The specific materials of concern are mainly $\mathrm{Mo}-\mathrm{Si}-\mathrm{B}$ intermetallics and $\mathrm{SiC}-\mathrm{SiC}$ ceramic composites; although, carbon fibers are also considered in this issue. Except for carbon fibers, the specific advantages of these materials are their potential to be used at very high temperatures (over $1,500{ }^{\circ} \mathrm{C}$ ) and their ability to grow protective silica layers. Even so, special attention is paid to the role played by additions like $\mathrm{La}_{2} \mathrm{O}_{3}, \mathrm{~B}, \mathrm{Hf}$, Dy, and Ti, which are present in order to positively impact hightemperature corrosion behavior and/or the mechanical properties of these materials.

The following key papers stem from presentations that were given at the 8th international conference on High Temperature Corrosion and Protection of Materials (HTCPM2012), which was held at Les Embiez Island, France, on the 20-25th of May 2012.

\footnotetext{
S. Chevalier $(\bowtie)$

ICB Laboratory CNRS, University of Bourgogne, 9 Avenue Savary, 21078 Dijon, France e-mail: Sebastien.Chevalier@u-bourgogne.fr

B. Pint

Materials Science and Technology Division, Oak Ridge National Laboratory, Oak Ridge, TN 37831-6156, USA

e-mail: pintba@ornl.gov

D. Monceau

INP Toulouse-CNRS, CIRIMAT, 31030 Toulouse, France

e-mail: daniel.monceau@ensiacet.fr
} 